
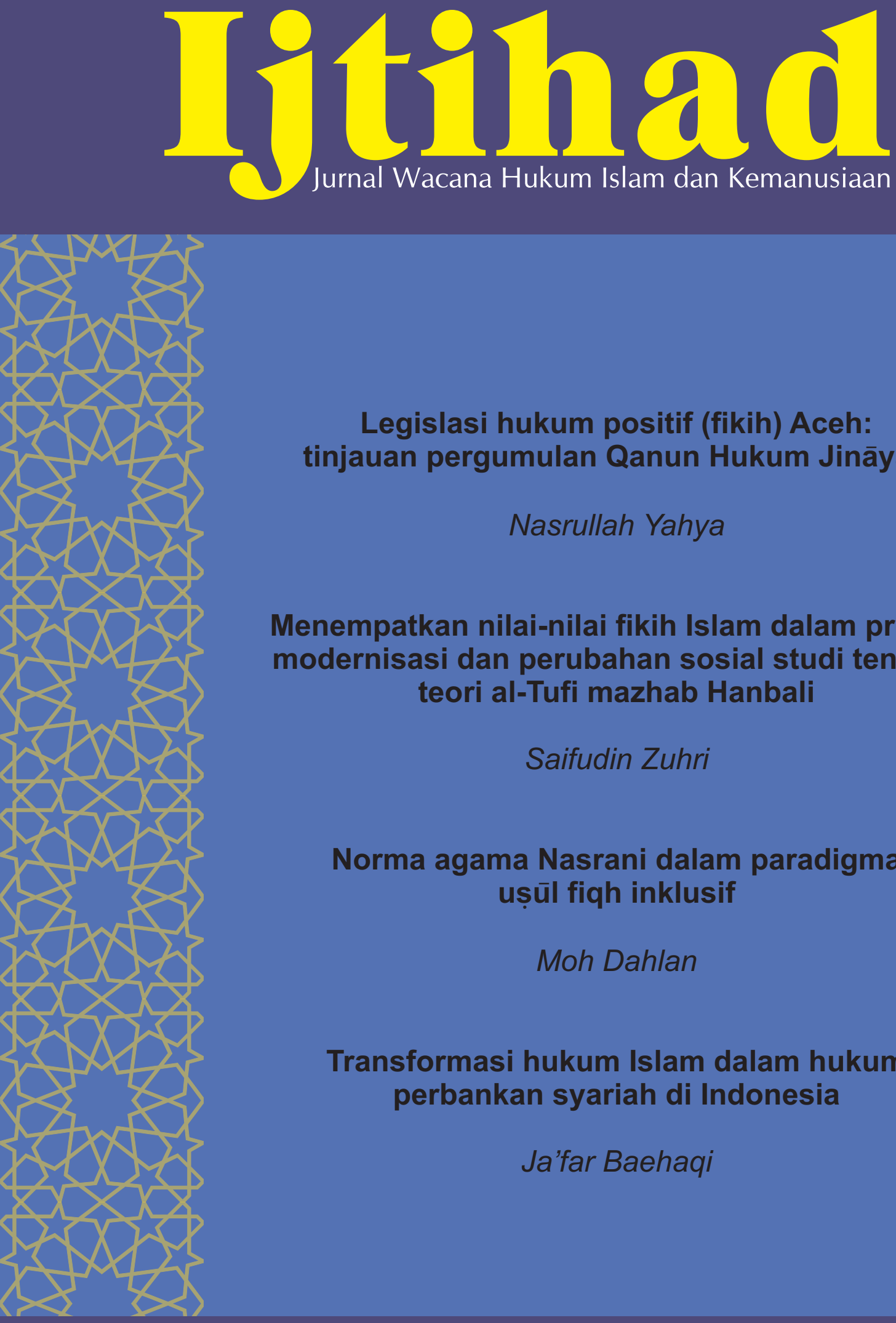

Legislasi hukum positif (fikih) Aceh: tinjauan pergumulan Qanun Hukum Jināyāh

\author{
Nasrullah Yahya
}

Menempatkan nilai-nilai fikih Islam dalam proses modernisasi dan perubahan sosial studi tentang teori al-Tufi mazhab Hanbali

Saifudin Zuhri

Norma agama Nasrani dalam paradigma ușūl fiqh inklusif

Moh Dahlan

Transformasi hukum Islam dalam hukum perbankan syariah di Indonesia

Ja'far Baehaqi 


\section{Ijtihad \\ Vol. 14, No. 2, Desember 2014}

\section{Daftar isi}

Legislasi hukum positif (fikih) Aceh: tinjauan pergumulan Qanun Hukum Jināyāh

Nasrullab Yabya • 149-166

Menempatkan nilai-nilai fikih Islam dalam proses modernisasi dan perubahan sosial studi tentang teori al-Tufi mazhab Hanbali

Saifudin Zubri • 167-187

Norma agama Nasrani dalam paradigma uṣūl fiqh inklusif

Mob Dablan • 189-209

Transformasi hukum Islam dalam hukum perbankan syariah di Indonesia Ja'far Baehaqi • 211-230

Akar, posisi, dan aplikasi adat dalam hukum

Abwan Fanani - 231-250

Bayang-bayang teori keagenan pada produk pembiayaan perbankan syariah Misnen Ardiansyah • 251-269

Dimensi politik hukum dalam perkembangan ekonomi Islam di Indonesia Bambang Iswanto • 271-284

Book Review:

Kritik otoritas pemaknaan hadis menuju masyarakat Islam berkemajuan Mubammad Irfan Helmy • 285-297 



\title{
Transformasi hukum Islam dalam hukum perbankan syariah di Indonesia
}

\author{
Ja'far Baehaqi \\ Fakultas Syari'ah IAIN Walisongo \\ Jalan Prof. Dr. Hamka Km. 1,5 Kampus III Ngaliyan Semarang 50185 \\ E-mail:baebaqi1@yahoo.co.id
}

Islamic law and Islamic banking law are two different entities, although both are substantially identical. This paper seeks to answer the question related to the transformation of Islamic law in Islamic banking law in the context of positivization of law. The study focused on the dialectic of Islamic law and national law in the formulation of Islamic banking law. With a history of regulatory approach, this study found that transformed the Islamic banking law is aspects of shariah compliance, is not Islamic law referred to in fikih muamalah. Sharia compliance is dynamic both in terms of substance, structure and culture.

Hukum Islam dan hukum perbankan syariah merupakan dua entitas yang berbeda, meskipun secara substansial keduanya identik. Makalah ini berupaya menjawab persoalan terkait transformasi hukum Islam dalam hukum perbankan syariah dalam konteks positivisasi hukum. Kajian difokuskan pada dialektika hukum Islam dan hukum nasional dalam formulasi hukum perbankan syariah. Dengan pendekatan sejarah perundang-undangan, kajian ini menemukan bahwa yang ditransformasikan dalam hukum perbankan syariah adalah aspek kepatuhan syariah, bukan hukum Islam sebagaimana dimaksud dalam fikih muamalah. Kepatuhan syariah ini bersifat dinamis baik dari sisi substansi, struktur maupun kultur.

Keywords: Islamic law; Sharia compliance; Transformation; Islamic banking

\section{Pendahuluan}

Meskipun UU yang khusus mengatur perbankan syariah baru disahkan pada 2008, yakni UU Nomor 21 Tahun 2008 tentang Perbankan Syariah (selanjutnya disebut UUPbS) sementara perbankan syariah telah eksis semenjak awal dasawarsa 1990-an, bukan berarti 
selama kurun waktu hampir dua dasawarsa tersebut hukum perbankan syariah belum ada. Sebelum disahkannya UU PbS pengaturan tentang perbankan syariah menyatu dalam UU Nomor 7 Tahun 1992 tentang Perbankan (UUP) dan UU Nomor 10 Tahun 1998 tentang Perubahan Nomor 7 Tahun 1992 tentang Perbankan (UUP Baru) beserta peraturan pelaksanannya baik berupa Peraturan Pemerintah, Peraturan Menteri Keuangan, Keputusan Direksi Bank Indonesia, Peraturan Bank Indonesia, dan Surat Edaran Bank Indonesia. Pengaturan perbankan syariah sejak awal kelahiran hingga disahkannya UU PbS penuh dengan dinamika dari sisi kelembagaan, kegiatan usaha maupun cara dan proses dalam melaksanakan kegiatan usaha oleh bank syariah.

Hukum perbankan syariah merupakan pengaturan teknis operasional perbankan pada satu sisi, dan pengaturan terkait kepastian pemenuhan prinsip hukum Islam di sisi lain. Karena itu pengaturan perbankan syariah tidak bisa dilepaskan dari hukum Islam. Dengan kata lain, hukum perbankan syariah merupakan hasil hubungan dialektika hukum nasional —-terutama yang mengatur tentang perbankan — dan hukum Islam — terutama yang mengatur kegiatan ekonomi (fikih muamalah). Tanpa keterlibatan hukum Islam, hukum perbankan syariah tidak akan pernah ada. Sebaliknya, hukum perbankan syariah tidak akan terbentuk tanpa hukum nasional. Demikian pula, keberadaan hukum nasional dan hukum Islam tidak serta merta melahirkan hukum perbankan syariah, tanpa ada persentuhan/persinggungan antara keduanya melalui hubungan dialektis.

Hukum perbankan syariah tidak identik dengan hukum Islam itu sendiri, meskipun kemunculannya berangkat dan dilatari oleh motif pelaksanaan ajaran Islam. Hukum perbankan syariah, mau tidak mau, harus memadukan hukum Islam dan hukum nasional yang mengatur tentang perbankan, terutama perbankan konvensional. Dalam formulasi hukum perbankan syariah hukum Islam ditantang untuk beradaptasi pada hal-hal di luarnya. Dengan demikian, hukum perbankan syariah selalu dihadapkan pada persoalan pemenuhan prinsip hukum Islam di satu sisi, dan pemenuhan prinsip bisnis perbankan yang baik di sisi yang lain.

Persoalan yang relevan dikemukakan di sini adalah bagaimanakah transformasi hukum Islam dalam hukum perbankan syariah? Makalah ini mencoba untuk mendiskripsikan dan menganalisis bagaimana perkembangan istilah yang dipakai dalam terminologi hukum perbankan syariah, urgensi pengaturan hukum perbankan syariah, prinsip syariah sebagai 
dasar operasional perbankan syariah, fatwa DSN MUI sebagai penerjemah prinsip syariah dan baru kemudian pada transformasi hukum Islam dalam hukum perbankan syariah.

\section{Syariah dan hukum Islam}

Sebagaimana telah dikemukakan dalam paragraf terdahulu kemunculan perbankan syariah berangkat dan dilatari oleh motif pelaksanaan ajaran Islam dalam operasional perbankan. Namun hingga dua dekade keberadaannya, istilah Islam dan hukum Islam hampir tidak diketemukan dalam khazanah terminologi yang dipakai dalam perbankan syariah dan hukum perbankan syariah. Sebaliknya yang sering dijumpai adalah istilah syariah dan prinsip syariah. Yang pertama menjadi trade merk dari sebuah entitas baru perbankan non konvensional, sedangkan yang kedua merupakan dasar operasional dari entitas baru perbankan dimaksud. Untuk itu diperlukan penjelasan mengenai arti istilah-istilah tersebut dan perkembangan pemakaiannya dari waktu ke waktu.

Ada tiga istilah yang sering diidentikkan, meskipun sebenarnya masing-masing mempunyai pengertian yang berbeda. Ketiga istilah itu adalah syari'at (Islam), fikih dan hukum Islam. Istilah syari'at pada awalnya mengacu pada keseluruhan ajaran Islam yang dibawa oleh Rasulullah Saw berdasarkan wahyu Allah Swt. Dari pengertian ini, maka syariah identik dengan (agama) Islam itu sendiri (Basyir, 1993: 5). Namun belakangan, syariah juga dipahami sebagai ajaran Islam yang berkaitan dengan perbuatan praktis yang bersifat otentik dan berasal secara langsung dari wahyu Allah (baik dalam al-Qur'an maupun Sunnah) yang semua orang sepakat adanya. Fikih adalah ilmu tentang — atau — kumpulan hukum-hukum syara' yang bersifat praktis yang diperoleh dari dalil-dalil yang terinci. Sedangkan istilah hukum Islam adalah berasal dari para sarjana Barat dan merupakan terjemahan dari istilah Islamic Law. Istilah hukum Islam dipahami sebagai seperangkat peraturan berdasarkan wahyu Allah dan Sunnah Rasul tentang tingkah laku manusia yang diakui dan diyakini berlaku dan mengikat untuk semua yang beragama Islam. Dari pengertian-pengertian ini maka dapat disimpulkan (1) bahwa fikih merupakan bagian dari syari'at, dan (2) bahwa fikih dan hukum Islam mempunyai arti yang berdekatan -atau bahkan sama? Karena itu sering orang mengidentikkan fikih dan hukum Islam (Syarifuddin, 1993: 13-19; Rofiq, 2000: 1-2; Shiddieqy, 1994: 22-32). 
Istilah hukum Islam, dengan demikian, identik dengan agama Islam dan Syari'at Islam itu sendiri, sehingga mencakup ketiga bidang itu secara keseluruhan. Dengan kata lain, sesungguhnya fikih merupakan bagian dari hukum Islam, bukan hukum Islam itu sendiri. Namun, karena fikih menyangkut perbuatan-perbuatan nyata dan praktis yang berlaku seharihari, maka ia mendominasi nama hukum Islam dan bahkan menjadi trade marknya (Yafie, 1994: 113-114).

Hukum Islam dalam makalah ini dimaknai sebagai hukum agama Islam yang berkaitan dengan perbuatan/tindakan yang terambil dari dalil-dalilnya yang spesifik (Khallaf, 1398: 11; Zuhayli, 1995: 14; Azizy, 2004: 185). Menurut Mudzhar (1998: 91-93), hukum Islam ini mewujud dalam berbagai bentuk, antara lain fatwa ulama atau mufti, putusan pengadilan agama, produk perundangan di negara muslim, dan kitab/buku fikih. Fatwa ulama atau mufti, baik secara individual maupun kolektif, bersifat kasuistik. Ia muncul sebagai respon atau jawaban pertanyaan yang diajukan oleh peminta fatwa. Fatwa tidak mempunyai daya ikat secara formal. Artinya, peminta fatwa tidak harus mengikuti isi atau hukum fatwa yang diberikan. Kekuatan mengikat fatwa hanya berasal dari dalam diri seseorang. Seorang muslimin atas dasar keimanannya terikat untuk melaksanakan dan mengikuti isi fatwa. Karena sifatnya yang responsif, fatwa biasanya cenderung bersifat dinamis, meskipun isinya sendiri kadang tidak dinamis.

Bentuk hukum Islam yang kedua adalah keputusan pengadilan agama. Berbeda dengan fatwa, keputusan pengadilan agama bersifat mengikat kepada pihak-pihak yang berperkara. Namun pada sisi yang lain, sama seperti halnya fatwa, keputusan pengadilan agama sampai tingkat tertentu bersifat dinamis. Sebab, ia merupakan usaha untuk memberikan jawaban atau menyelesaikan masalah yang diajukan ke pengadilan.

Bentuk hukum Islam yang ketiga, yaitu perundangan di negeri muslim bersifat mengikat dengan daya ikat yang lebih luas. Pihak yang terlibat dalam perumusannya tidak terbatas pada para fuqaha atau ulama, tetapi juga para politisi dan cendekiawan lainnya. Bahkan para politisi di parlemen adalah penentu akhir dari proses perumusannya, baik lewat musyawarah mufakat maupun melalui mekanisme voting. Masa laku peraturan perundangan dinyatakan, baik waktu bermulanya maupun berakhirnya. Kalaupun waktu berakhirnya tidak dinyatakan, maka dengan sendirinya masa berakhirnya itu menjadi ada ketika peraturan perundangan 
yang lain yang mengatur obyek yang sama telah disahkan baik secara eksplisit dinyatakan sebagai pengganti/pencabut peraturan perundangan terdahulu/yang telah ada atau tidak dinyatakan.

Bentuk hukum Islam yang keempat adalah kitab/buku fikih. Kitab/buku fikih ini kebanyakan adalah karya ulama secara individual dan jarang sekali yang merupakan karya bersama. Pada saat ditulis oleh pengarangnya kitab/buku fikih tidak dimaksudkan untuk diberlakukan secara khusus atau secara umum di suatu tempat/negeri, meskipun dalam sejarah ada beberapa kitab fikih tertentu yang difungsikan sebagai kitab undang-undang. Sebagai karya intelektual, kitab/buku fikih juga tidak pernah dimaksudkan oleh pengarangnya untuk digunakan pada masa atau periode tertentu. Dengan tidak adanya keterangan tempat dan masa berlaku, maka kitab/buku fikih cenderung dianggap harus/bisa berlaku di mana saja dan kapan saja. Hal demikian dalam satu perspektif menimbulkan kejumudan atau kebekuan berpikir karena orang cenderung menganggap kitab/buku fikih yang ada adalah barang jadi yang tinggal digunakan dan oleh sebab itu ia enggan berpikir ulang. Selain itu, tidak seperti fatwa dan keputusan pengadilan agama yang bersifat kasuistik dengan membahas masalah tertentu, kitab/buku fikih kebanyakan bersifat menyeluruh dan meliput semua aspek hukum Islam. Sebagai akibat dari sifatnya yang menyeluruh ini, maka perbaikan atau revisi terhadap sebagian isi kitab/buku fikih dianggap dapat atau akan mengganggu keutuhan isi keseluruhannya. Karena itu semua, kitab/buku fikih resisten terhadap perubahan.

Istilah syariah yang melekat pada sebutan bank syariah, baik bank umum maupun bank pembiayaan rakyat, mengandung arti agama Islam dan hukum Islam. Sehingga dengan demikian, bank syariah diartikan sebagai bank yang beroperasi menurut ajaran agama Islam atau hukum Islam. Pemakaian kata syariah sebagai nama bank, bukannya kata Islam sebagaimana di Malaysia dan negara-negara Islam lain, merupakan persoalan strategi saja. Sebab, waktu itu kata Islam menjadi alergi bagi banyak kalangan terutama mereka yang mengalami sindrom Islamic phobia.

\section{Urgensi pengaturan hukum perbankan syariah}

Formulasi hukum perbankan Syariah di Indonesia merupakan problematik. Ia bukan persoalan positivisasi hukum Islam semata, namun lebih dari itu, sebagaimana dikemukakan 
Azizy (2004: 11-13) ia merupakan persoalan bagaimana eklektisisme (memilah dan memilih) bisa dilakukan antara hukum Islam dan hukum nasional. Problematika formulasi hukum perbankan Syariah muncul karena banyak hal. Pertama, fikih muamalah sebagai hukum Islam yang membidangi persoalan ekonomi, tidak identik dengan perbankan syariah itu sendiri. Fikih muamalah/hukum ekonomi Islam hanya mengatur hal-hal yang bersifat prinsip-prinsip saja. Sedangkan praktek dan operasional perbankan saat ini sudah sedemikian rumit dan detailnya, sehingga transformasi fikih mumalah ke hukum perbankan syariah tidak akan operasional jika tidak diikuti oleh penyiapan sarana prasarana dan infrastruktur yang menunjang.

Kedua, hukum ekonomi Islam atau tepatnya prinsip syariah yang menjadi dasar operasional bank syariah adalah fatwa dari Dewan Syariah Nasional Majelis Ulama Indonesia (DSN MUI), bukan karya hukum Islam yang telah terkodifikasikan secara detail. Memang prinsip syariah itu pada akhirnya terkodifikasikan, akan tetapi sebelum sampai ke sana fatwa DSN MUI itu diolah terlebih dahulu oleh Komite Perbankan Syariah yang dibentuk oleh Bank Indonesia. Prinsip syariah dimaksud, menurut Pasal 26 ayat (3) UU PbS, baru mendapatkan kekuatan yuridisnya setelah dituangkan dalam bentuk Peraturan Bank Indonesia (PBI) dalam format kodifikasi. Karakteristik hukum Islam yang berbentuk fatwa adalah sifat dinamisnya. Ia mudah menyesuaikan dengan perkembangan zaman sehingga membuatnya senantiasa relevan dan aktual setiap saat. Namun pada sisi yang lain, hukum Islam yang berbentuk fatwa tidak mempunyai daya ikat termasuk kepada pencari/peminta fatwa, kecuali atas dasar keyakinan keimanannya (Mudzhar, 1998: 91-93; Yafie, 1994: 89-90; Baehaqi, 1999: 59-60). Kecuali itu, transformasi fatwa menjadi PBI yang butuh proses panjang demi terpenuhinya persyaratan yuridis memunculkan persoalannya sendiri. Ialah persoalan hasil akhir dari fatwa tersebut.

Ketiga, hukum ekonomi Islam terutama yang terkait dengan perbankan tidak bisa terakomodir oleh sistem perbankan yang ada yang mendasarkan operasionalnya dengan sistem bunga. Oleh karena itu hukum perbankan Syariah harus diramu dari prinsip-prinsip hukum ekonomi Islam dan hukum nasional yang telah ada, baik hukum perbankan (non Syariah)-nya maupun bidang hukum yang lain. Hukum perbankan Syariah, dengan demikian, tampil sebagai entitas baru dan dalam banyak hal berbeda dari hukum perbankan non 
Syariah. Jadi, baik dalam praktek maupun dasar hukumnya, perbankan Syariah banyak berbeda dari perbankan non Syariah.

Keempat, hukum perbankan Syariah merupakan bagian dari peraturan perundangundangan. Konsekwensinya, ia senantiasa terkait secara sinergis dan harmonis dengan produkproduk peraturan perundang-undangan yang lain, baik yang secara spesifik mengatur perbankan maupun yang mengatur perekonomian secara umum, bahkan dengan sistem hukum nasional yang telah dan akan ada secara keseluruhan. Jika tidak, maka akan terjadi ketimpangan dan disharmoni serta ketidaksingkronan yang akan membuat hukum perbankan Syariah tidak operasional dan a-historis.

\section{Prinsip syariah sebagai dasar operasional perbankan syariah}

Karakteristik operasional perbankan syariah, sebagaimana dikemukakan dalam paragraf terdahulu, adalah keharusan pemenuhan hukum Islam. Inilah yang membedakannya dengan operasional perbankan konvensional. Dalam konteks ini perbankan syariah mengelaborasi pelarangan riba dan pembebasan transaksi-transaksinya dari unsur-unsur ribawi. Sebagai langkah praksisnya hukum perbankan syariah mengintroduksi prinsip bagi hasil sebagai dasar operasional. Dalam perkembangannya istilah prinsip bagi hasil digantikan oleh istilah prinsip syariah.

Sebagai peraturan perundang-undangan pertama yang mengintroduksi prinsip bagi hasil, UUP hanya menyebutkan istilah bagi hasil dalam dua konteks. Pertama, konteks pendefinisian kredit dalam kaitannya dengan imbalan yang harus diberikan oleh peminjam. Di sini, sebagaimana dinyatakan dalam Pasal 1 angka 12, peminjam diharuskan melunasi utangnya setelah jangka waktu tertentu dengan imbalan atau pembagian hasil keuntungan. Kedua, konteks pengaturan kegiatan usaha bank syariah, baik bank umum maupun bank pembiayaan rakyat. Di sini, Pasal 6 huruf $m$ dan Pasal 13 huruf c menyebut istilah prinsip bagi hasil sebagai dasar operasional dalam penyediaan pembiayaan bagi nasabah.

Pengaturan prinsip bagi hasil sebagai dasar operasional bank syariah dalam penyediaan pembiayaan tersebut dibatasi oleh keharusan kesesuaiannya dengan ketentuan yang ditetapkan dalam Peraturan Pemerintah. Benar saja, dengan diterbitkannya Peraturan Pemerintah Nomor 72 Tahun 1992 tentang Bank Berdasarkan Prinsip Bagi Hasil (PP BBH) maka segala hal yang 
terkait dengan bank syariah dan prinsip bagi hasil yang menjadi basis operasionalnya harus merujuk kepada PP dimaksud.

Ada dua hal yang penting dicatat terkait dengan operasionalisasi prinsip bagi hasil sebagaimana dinyatakan dalam PP BBH. Pertama, pada dasarnya istilah bagi hasil itu mengandung pengertian yang umum dan tidak terkait dengan ajaran agama tertentu, terutama Islam. Untuk itu PP BBH melalui penjelasan Pasal 1 membatasi pengertian bagi hasil itu dengan prinsip muamalat berdasarkan syari'at dalam melakukan kegiatan usaha bank. Meskipun PP BBH sama sekali tidak menyebut Islam dalam menjelaskan prinsip bagi hasil, namun pemakaian istilah muamalat dan syariah telah cukup sebagai informasi bahwa yang dimaksud adalah prinsip bagi hasil sebagaimana diatur dalam fikih muamalah (hukum ekonomi islam) yang merupakan bagian dari ajaran syariat Islam.

Kedua, dari penjelasan prinsip bagi hasil itu dapat dipahami bahwa dasar operasional bank syariah bukan semata prinsip bagi hasil melainkan juga prinsip yang lain sebagaimana dikenal dalam fikih muamalah, seperti jual beli dan kegiatan-kegiatan usaha yang lain yang lazim dilakukan oleh bank syariah, terutama di luar negeri (Perwataatmadja, 2012; dan Antonio, 2001: 22-25). Hal ini nampak dari pengaturan lebih lanjut tentang penerapan prinsip bagi hasil sebagaimana secara eksplisit dinayatakan dalam Pasal 2 PP BBH. Dengan demikian, penyebutan bagi hasil sebagai suatu prinsip operasional bank syariah tidak dimaksudkan secara sempit dan apa adanya, tetapi hanya sebagai sebutan antara di mana sesungguhnya yang dimaksud lebih luas darinya. Ialah prinsip bertransaksi sebagaimana diatur dalam fikih muamalah.

Bagi hasil dalam hukum Islam mengambil bentuk yang beraneka ragam, tergantung tipe usaha yang dilakukan atau kecenderungan dari para pihak. Apabila modal berasal dari satu pihak, sedangkan pihak yang lain hanya menjalankan bisnis, maka bentuknya adalah mudärabah. Apabila modal berasal dari para pihak, dua pihak atau lebih, maka bentuknya adalah mushärakah atau perkongsian.

Dalam kenyataannya, kegiatan usaha bank berdasarkan prinsip bagi hasil tidak hanya berbentuk mudārabah dan musyarakah sebagaimana dimaksud di atas, tetapi juga meliputi kegiatan jual beli dan berbagai kegiatan usaha lain yang telah lazim dilakukan oleh bank berdasarkan prinsip bagi hasil yang telah beroperasi, baik di dalam maupun di luar negeri. 
Dengan demikian, penyebutan bank bagi hasil merujuk pada sebagian kegiatan usaha yang dijalankan oleh bank yang bersangkutan, sebagai kegiatan usaha yang dominan. Atau dapat pula dikatakan bahwa penyebutan bank bagi hasil merujuk pada pola kerja yang dipakai oleh bank yang bersangkutan dalam menjalankan bisnisnya. Hubungan bank dengan nasabahnya bukan merupakan hubungan kreditur-debitur, tetapi hubungan partnership. Hubungan demikian mensyaratkan kesejajaran antar pihak dalam menjalankan usaha, di mana masing-masing berada dalam posisi yang sama terkait potensi hasil/keuntungan yang ingin dicapai maupun potensi kerugian yang bakal diderita. Artinya, para pihak yang berpartner sama-sama berada dalam posisi yang tidak pasti, apakah akan mendapatkan keuntungan dari hasil usahanya yang dijalankan atau sebaliknya menderita kerugian (Buang dan Nafis, 2012: 60).

Pasca krisis ekonomi di Indonesia yang mengakibatkan jatuhnya kekuasaan Orde Baru untuk kemudian digantikan dengan Orde Reformasi, UUP diamandemen dan disempurnakan dengan UUP Baru. UUP Baru mengelaborasi istilah prinsip syariah sebagai ganti istilah prinsip bagi hasil. UUP Baru kecuali memberikan pengaturan prinsip syariah yang lebih memadai di satu sisi, juga secara eksplisit menjelaskan pengertiannya dalam kaitannya dengan hukum Islam di sisi yang lain. Pasal 1 angka 13 UUP Baru mendefinisikan prinsip syariah sebagai:

"aturan perjanjian berdasarkan hukum Islam antara bank dan pihak lain untuk penyimpanan dana dan atau pembiayaan kegiatan usaha, atau kegatan lainnya yang dintakan sesuai dengan syariah, antara lain pembiayaan berdasarkan prinsip bagi hasil (mudharabah), pembiayaan berdasarkan prinsip penyertaan modal (musyarakah), prinsip jual beli barang dengan memperoleh keuntungan (murabahah), atau pembiayaan barang modal berdasarkan prinsip sewa murni tanpa pilihan (ijarah), atau dengan adanya pilihan pemindahan kepemilikan atas barang yang disewa dari pihak bank oleh pihak lain (ijarah wa iqtina).

Definisi prinsip syariah itu kemudian disempurnakan oleh UU PbS dengan kalimat yang pendek namun mengena sekaligus menentukan kriterianya dalam konteks asal-usul dan sumbernya. Pasal 1 angka 12 UU PbS mendefinsikan prinsip syariah sebagai prinsip hukum Islam dalam kegiatan perbankan berdasarkan fatwa yang dikeluarkan oleh lembaga yang memiliki kewenangan dalam penetapan fatwa di bidang syariah. 
Ijtihad, Jurnal Wacana Hukum Islam dan Kemanusiaan, Volume 14, No. 2, Desember 2014: 211-230

Kerangka yuridis prinsip syariah ini penting karena salah satu kegiatan usaha bank syariah adalah melakukan penyertaan modal, yaitu dalam bentuk transaksi musyarakah yang oleh Pasal 10 ayat (1) dan Pasal 14 huruf c dilarang dilakukan oleh bank umum syariah maupun bank perkreditan rakyat syariah. Sebab, penyertaan modal itu dilakukan oleh lembaga pembiayaan yang notabene bukan merupakan lembaga bank yang tunduk pada UU Perbankan lama maupun baru (Sjahdeini, 2007: 131-132).

Dengan demikian, legalitas kegiatan usaha bank syariah yang sebagian identik dengan kegiatan usaha lembaga pembiayaan telah mantap dengan adanya Pasal 1 angka 13 UUP Baru dan Pasal 1 angka 12 UU PbS tersebut. Dengan kata lain, secara yuridis tidak ada lagi persoalan tentang kegiatan usaha bank syariah terkait bentuk dan macamnya. Artinya bank syariah adalah bank, meskipun menjalankan usaha yang sebagiannya sama dengan kegiatan usaha lembaga pembiayaan oleh karena, betapa pun demikian, ia melaksanakan fungsi intermediasi keuangan sebagaimana layaknya sebuah bank. Ialah menghubungkan dua pihak yang saling membutuhkan, yaitu pihak surplus (penabung) dan pihak defisit (peminjam).

\section{Fatwa DSN MUI sebagai penerjemah prinsip syariah}

Adalah Pasal 5 ayat (1) PP BBH yang mengintrodusir Dewan Pengawas Syariah (DPS) dengan tugas melakukan pengawasan atas produk perbankan dalam menghimpun dana dari masyarakat dan menyalurkannya kepada masyarakat agar berjalan sesuai dengan prinsip syari'at. Dalam konteks ini DPS, sebagaimana penjelasan Pasal 5 ayat (1), bertugas menentukan boleh tidaknya suatu produk/jasa dipasarkan atau suatu kegiatan dilakukan ditinjau dari sudut syari'at.

Tugas pengawasan dalam rangka menjamin kepatuhan kepada prinsip syariah itu pada gilirannya mengharuskan DPS melaksanakan tugas lain yang sangat terkait dan bahkan menjadi asal muasal dari tugas pengawasan tersebut. Tugas lain itu adalah penerbitan fatwa syariah sebagai penerjemah sekaligus penjabaran prinsip syariah (Ali, 2010: 14). Pada awalnya, ketika bank syariah masih sangat terbatas jumlahnya, penerbitan fatwa yang dilakukan DPS identik dengan fatwa Majelis Ulama Indonesia (MUI) sebagai lembaga yang terlibat dalam pembentukannya. Waktu itu bank syariah identik dengan Bank Muamalat Indonesia (BMI) yang kelahirannya dibidani oleh MUI dan semua anggota DPSnya bahkan pimpinan MUI 
(Syam, 2010: 4-5) . Namun, dengan banyaknya bermunculan bank syariah di kemudian hari, penerbitan fatwa oleh masing-masing DPS dikhawatirkan akan menimbulkan banyak fatwa yang satu sama lain bertentangan. Kondisi demikian dianggap berbahaya, terutama dari sisi kepastian hukum Islam yang menjadi dasar operasional kegiatan usaha perbankan syariah.

Mengantisipasi kemungkinan terjadinya perbedaan pandangan dalam melihat suatu produk perbankan oleh masing-masing DPS, maka MUI membentuk Dewan Syariah Nasional (DSN). Pembentukan DSN merupakan langkah efisiensi dan koordinasi para ulama dalam menanggapi isu-isu yang berhubungan dengan masalah ekonomi/keuangan (Syam, 2011: 3). Melalui Dewan Syari'ah Nasional (DSN) ini MUI berperan dalam memberikan fatwa hukum yang berkaitan dengan operasional perbankan syariah dan bidang ekonomi syariah yang lain (Amin, 2012: 4; Buang dan Nafis, 2012: 58; dan Departemen Agama, t.th.: 13-19).

Keberadaan DSN-MUI segera saja mendapatkan respon dari Bank Indonesia selaku regulator di bidang perbankan — pasca disahkannya UUP Baru dan UU Nomor 23 Tahun 1999 tentang Bank Indonesia (UUBI). Tiga Surat Keputusan Direksi Bank Indonesia secara bersamaan memberikan tugas dan kewenangan kepada DSN-MUI untuk memastikan kesesuaian produk, jasa dan kegiatan usaha bank syariah dengan prinsip syariah. Tugas dan kewenangan ini dalam prakteknya terdiri dari penerbitan fatwa ekonomi syariah dan pembentukan DPS dalam tiap lembaga keuangan syariah, terutama bank syariah.

Paket SK Direksi BI yang memberikan tugas dan kewenangan kepada DSN-MUI adalah SK Direksi Bank Indonesia Nomor 32/33/KEP/DIR tentang Bank Umum, SK Direksi Bank Indonesia Nomor 32/34/KEP/DIR tentang Bank Umum Berdasarkan Prinsip Syariah, dan SK Direksi Bank Indonesia Nomor 32/36/KEP/DIR tentang Bank Perkreditan Rakyat Berdasarkan Prinsip Syariah. Ketika kemudian produk hukum yang dihasilkan Bank Indonesia selaku regulator berubah menjadi Peraturan Bank Indonesia (PBI), substansi ketiga SK Direksi tersebut secara berurutan dimuat ulang dalam PBI Nomor 2/27/PBI/2000 tentang Bank Umum, PBI Nomor 6/24/PBI/2004 tentang tentang Bank Umum yang Melaksanakan Kegiatan Usaha Berdasarkan Prinsip Syariah, PBI Nomor 6/17/PBI/2004 tentang Bank Perkreditan Rakyat Berdasarkan Prinsip Syariah dan PBI-PBI perubahan masingmasing. 
Tugas penerbitan fatwa ekonomi syariah dan pembentukan DPS diperkuat eksistensinya dalam UU PbS. Yang pertama tampak ketika Pasal 1 angka 12 UU PbS mendefnisikan prinsip syariah, sebagaimana dikemukakan dalam paragraf terdahulu, dan kemudian dinyatakan ulang ketika UU PbS mengharuskan kegiatan usaha dan/atau produk dan jasa yang diberikan bank syariah tunduk kepada prinsip syariah. Selanjutnya dalam Pasal 26 ayat (1) dan (2) secara eksplisit dinyatakan bahwa prinsip syariah tersebut difatwakan oleh DSNMUI. Sedangkan terkait pembentukan DPS UU PbS mereposisi peran DSN-MUI dari semula sebagai lembaga yang berwenang membentuk menjadi hanya sebatas pengusul dan pemberi rekomendasi. Dengan maksud memperkuat keberadaan DPS, Pasal 32 ayat (2) UU PbS menyatakan bahwa DPS diangkat oleh Rapat Umum Pemegang Saham (RUPS) atas rekomendasi DSN-MUI.

\section{Transformasi hukum Islam}

Uraian sepintas tentang prinsip syariah dalam paragraf terdahulu menginformasikan bahwa hukum Islam yang menjadi dasar operasional perbankan syariah mempunyai karakteristik tersendiri. Pada awalnya hukum Islam itu identik dengan fatwa dan/atau opini hukum DPS pada masing-masing bank syariah. Hal ini berlangsung selama kurang lebih tujuh tahun sejak disahkannya UUP hingga disahkannya UUP Baru (1992 - 1999). Fatwa dan/atau opini hukum DPS yang menjadi acuan operasional bank syariah selama kurun waktu ini bersifat tertutup/eksklusif/internal bagi bank syariah yang bersangkutan dan oleh karena itu hanya mengikat secara eksklusif pada bank syariah tersebut. Dengan kata lain, fatwa dan/atau opini hukum DPS pada masing-masing bank syariah merupakan dokumen milik bank syariah yang bersangkutan. Sebagai demikian, hukum Islam yang menjadi acuan operasional bank syariah bisa berbeda antara satu bank syariah dengan bank syariah lainnya. Artinya, tidak ada kesatuan dan kepastian mengenai hukum Islam dimaksud. Hal demikian sangat logis mengingat adanya banyak madzhab dalam hukum Islam, di mana perbedaan tidak saja terjadi antar madzhab tersebut melainkan juga di dalam internal masing-masing madzhab.

Dengan dibentuknya DSN-MUI dan kemudian diakui sebagai satu-satunya lembaga yang mempunyai tugas dan wewenang untuk memastikan kesesuaian produk, jasa dan kegiatan usaha bank syariah dengan prinsip syariah, maka ada kepastian hukum Islam yang menjadi 
acuan operasional bank syariah. Ialah hukum Islam yang difatwakan oleh DSN-MUI.

Fatwa DSN mempunyai kedudukan yang unik terkait dengan daya ikatnya. Sebagai fatwa keagamaan yang dikeluarkan oleh institusi yang mempunyai otoritas di bidangnya, fatwa DSN hanya mengikat atas dorongan keimanan, sama seperti hukum Islam pada umumnya. Dalam ungkapan yang lain materi muatan fatwa DSN itu menjadi doktrin hukum substantif Islam/fikih (Anwar, 2007: 302-303). Namun, pada sisi yang lain, sebagai fatwa yang dikeluarkan sebuah institusi yang telah ditunjuk dan diberikan wewenang oleh peraturan perundang-undangan yang berlaku, fatwa DSN mengikat kepada semua orang yang berkepentingan terhadap materi yang difatwakan (pelaku ekonomi syariah), terlepas apakah mereka itu peminta fatwa atau bukan. Terlebih lagi, sebagian besar fatwa-fatwa DSN itu telah diserap, diadopsi, atau dimuat ulang dalam peraturan perundang-undangan, yakni UU PbS dan berbagai Peraturan Bank Indonesia, maka daya ikatnya bersifat mutlak (bandingkan Umam, 2012: 368).

Sejak berdiri hingga sekarang, DSN telah menerbitkan 82 fatwa tentang ekonomi syariah. Sebagian besar fatwa DSN merupakan jawaban atas masalah-masalah perbankan syariah (58 fatwa), asuransi syariah (6 fatwa), pasar modal syariah (10 fatwa), pembiayaan syariah (1 fatwa), pegadaian syariah (3 fatwa), surat berharga syariah (3 fatwa), akuntansi syariah (1 fatwa), dan jasa perjalanan umrah (1 fatwa) (Syam, 2012; Maksum, 2011: 566; dan Mudzhar, 2012: 3).

Sebagaimana telah dijelaskan dalam uraian terdahulu fatwa merupakan salah satu bentuk hukum Islam (fikih) di samping kitab/buku fikih, putusan pengadilan dan produk peraturan perundang-undangan. Sebagai sama-sama hukum Islam fatwa mempunyai karakteristik yang tidak dipunyai oleh tiga bentuk hukum Islam yang lain. Karakteristik fatwa adalah sifat dinamisnya oleh karena ia muncul selain didasarkan atas nuṣuș shar'iyyah (teks-teks suci) juga didasarkan atas refleksi dari kondisi sosial yang melingkupinya. Sedemikian besar pengaruh kondisi sosial terhadap lahirnya fatwa, sehingga dikatakan bahwa relevansi sebuah fatwa sangat bergantung pada kondisi sosial yang melingkupinya tersebut. Pertanyaan yang diajukan peminta fatwa (mustafti) merupakan refleksi sosial dimaksud. Karena karakteristiknya ini yakni, sebagai hasil mendialogkan kondisi sosial dengan naș_- fatwa sangat mungkin berbeda dari materi hukum Islam yang termaktub dalam buku fikih misalnya. 
Ijtihad, Jurnal Wacana Hukum Islam dan Kemanusiaan, Volume 14, No. 2, Desember 2014: 211-230

Fatwa DSN-MUI pun, sebagaimana dikemukakan Amin (2012: 3) boleh jadi dalam hal-hal tertentu tidak sama dengan kesimpulan hukum yang termaktub dalam buku fikih terdahulu. Hal itu terjadi karena ditemukannya sesuatu yang baru yang menjadi 'illah hukum (legal reason) yang tidak ditemukan di waktu yang lampau. Perkembangan permasalahan di bidang ekonomi saat ini sangat pesat dan cepat. Fatwa DSN-MUI sebagai hasil ijtihad jama ‘ $i$ (kolektif) merupakan jawaban dan respon atas permasalahan perekonomian tersebut. Adanya kemungkinan perbedaan antara fatwa DSN-MUI dari materi yang termaktub dalam buku fikih tidak mengurangi nilai keabsahan dan validitas fatwa. Sebab, meskipun berbeda, keduanya mempunyai ruh yang sama, yakni mewujudkan tujuan utama syariat (taḥ̂̄iq maqașid al-shäri'ah).

Dalam kadar dan tataran tentu fatwa DSN-MUI secara sadar dimaksudkan untuk melakukan pembaharuan hukum Islam di bidang ekonomi. Pembaharuan ini tidak dalam arti menciptakan hukum yang sama sekali baru dan tidak terkait dengan pendapat ulama terdahulu. Pembaharuan hukum Islam oleh DSN-MUI lebih ditekankan pada pengujian validitas illah terhadap pendapat ulama terdahulu. Jika 'illahnya dipandang masih relevan dengan kondisi kekinian maka pendapat ulama tersebut akan dipakai. Sebaliknya jika illahnya dianggap sudah tidak cocok lagi dengan kondisi saat ini maka pendapat tersebut ditinggalkan, tetapi manhaj istinbăt al-ḥukm (metode penetapan hukum)-nya tetap dipakai oleh DSN-MUI. Dalam konteks pembaharuan hukum Islam, DSN-MUI mengelaborasi dua kaidah yang secara spesifik mendasari banyak fatwanya, yaitu kaidah tafrìq al-ḥalăl min al-ḥarä dan kaidah i'ädab al-nazar.

Kaidah tafriq al-ḥaläl min al-ḥaräm (pemisahan unsur halal dari yang haram) relevan dikembangkan di bidang ekonomi syariah karena kegiatan ekonomi syariah belum bisa terlepas sepenuhnya dari sistem ekonomi konvensional yang ribawi. Paling tidak, lembaga ekonomi syariah akan berhubungan dengan ekonomi konvensional yang ribawi dari aspek permodalan, pengembangan produk, dan aspek keuntungan yang diperoleh. Kaidah ini dapat dilakukan sepanjang unsur yang haram tidak lebih besar atau dominan dari unsur yang halal. Setelah unsur yang haram dan halal telah dapat diidentifikasi, maka unsur yang haram harus dikeluarkan. 
Kaidah ini dibangun atas dasar bahwa keharaman harta atau uang dalam perspektif fikih bukan karena dzatnya, tetapi karena cara memperolehnya. Oleh karena itu, apabila harta atau uang yang halal tercampur dengan yang haram, sedangkan masing-masing dapat diidentifikasi dan kemudian yang haram dikeluarkan, maka yang tersisa adalah halal hukumnya (Hosen, 2007: 30-31).

Kaidah i'ádab al-nazar (telaah ulang), yang dikembangkan sebagai sarana pembaharuan hukum ekonomi syariah, dilakukan dengan cara menguji kembali pendapat ulama terdahulu tentang suatu masalah. Telaah ulang terhadap pendapat ulama terdahulu ini dilakukan karena 'illah hukumnya telah berubah, tidak aplikatif, tidak memadai dengan kondisi kontemporer, atau dianggap tidak cocok lagi untuk dipedomani karena sulit diimplementasikan. Dalam konteks telaah ulang ini pendapat yang sebelumnya dipedomani (mu'tamad) diuji kembali dengan mempertimbangkan pendapat yang dipandang lemah (marjū bahkan mahjür), karena adanya illah hukum yang baru dan atau karena lebih membawa kemaslahatan. Dengan pertimbangan itu, pendapat yang semula dianggap lemah kini dijadikan pedoman dalam menetapkan hukum. Hal demikian sejalan kaidah ushul fikih: al-ḥukm yaduru ma'a 'illatih wujüdan wa'adaman.

Penerapan kaidah $i$ ádah al-nază merupakan suatu terobosan dalam pengembangan hukum Islam, terutama di bidang ekonomi yang selama ini mengalami kemandekan yang cukup lama di tengah hegemoni hukum bisnis dan hukum dagang konvensional. Pengembangan kaidah ini ke depan merupakan sikap yang lebih hati-hati dan terukur secara ilmiah daripada sikap longgar dalam menetapkan hukum dengan berlindung di bawah kaidah : al-asl fi al-


telah ada dalil yang mengharamkannya), adanya mashlahah atau hajah (kebutuhan yang mendesak). Pengembangan kaidah $i$ ádah al-nazar ini merupakan jalan tengah di antara dua pilihan ekstrim, yaitu (1) pemikiran sebagian pakar ekonomi Islam yang terlalu longgar dalam menerapkan prinsip-prinsip hukum ekonomi Islam sehingga terjebak pada labelling, dan (2) pemikiran ekonomi Islam yang terlalu ketat dan terikat dalam kaidah-kaidah dan pemikiran fikih klasik yang sulit diaplikasikan kembali pada era sekarang (Amin, 2012: 7).

Karakteristik fatwa-fatwa DSN-MUI yang demikian membuatnya mudah diterima oleh Bank Indonesia, Kementerian Keuangan, dan Badan Pengawas Pasar Modal dan Lembaga 
ljtihad, Jurnal Wacana Hukum Islam dan Kemanusiaan, Volume 14, No. 2, Desember 2014: 211-230

Keuangan (Bapepam LK) untuk kemudian diadopsi dalam peraturan perundang-undangan. Bahkan, sebagaimana dikemukakan Nafis (2011: 233-249), sebagian fatwa DSN-MUI diadopsi menjadi bagian dari Undang-Undang, setidaknya UU Nomor 21 tentang Perbankan Syariah dan UU Nomor 19 Tahun 2008 tentang Surat Berharga Syariah Negara.

Penyerapan fatwa DSN-MUI ke dalam UU PbS dan pendelegasian formulasi hukum Islam lebih lanjut kepada DSN-MUI membawa implikasi sebagai berikut. Pertama, fatwa DSN-MUI merupakan entitas yang sebanding dengan PBI sebagai produk hukum yang sama-sama diperintahkan dan diakui oleh UU PbS, meskipun fatwa DSN-MUI tidak termasuk kategori peraturan perundangan. Dengan demikian, fatwa DSN-MUI diakui dan diamanatkan untuk menjabarkan prinsip syariah yang merupakan unsur esensial dalam operasional perbankan syariah, sedangkan PBI diperintahkan untuk mengatur lebih lanjut implementasi fatwa DSN-MUI. Artinya keduanya merupakan pengaturan lebih lanjut dan mendapatkan amanat dari UU PbS.

Kedua, sebagai konsekwensi dari kesetaraan tersebut, eksistensi fatwa DSN-MUI bukan merupakan subordinat dari PBI. Eksistensi fatwa DSN-MUI adalah penunjang PBI dalam mengatur operasional perbankan syariah, sehingga keduanya perlu bersinergi. Dengan ungkapan yang lain, keberlakuan fatwa DSN-MUI telah diberikan dan dijamin oleh UU $\mathrm{PbS}$ secara langsung, sehingga tidak perlu lagi pemberlakuan dengan PBI. Kalaupun secara materi fatwa DSN-MUI dimuat ulang dalam PBI, maka hal tersebut harus dipahami dalam konteks mengoperasionalkan fatwa DSN-MUI dalam mekanisme kerja perbankan syariah, bukan dasar yuridis keberlakuannya.

Dengan demikian, keberadaan Komite Perbankan Syariah (KPS) sebagaimaan dielaborasi oleh UU PbS tidak diperlukan lagi. Menurut Pasal 26 UU PbS, KPS dibentuk dalam rangka penyusunan Peraturan Bank Indonesia yang mengatur fatwa DSN-MUI tentang penjabaran prinsip syariah yang menjadi acuan kegiatan usaha, produk dan/atau jasa bank syariah.

Munculnya KPS membuat alur transformasi hukum Islam dalam hukum perbankan syariah menjadi lebih rumit dan panjang serta mendegradasi validitas fatwa DSN-MUI. Dikatakan demikian, karena hukum Islam yang mewujud dalam fatwa DSN-MUI tidak saja harus diformulasikan ke dalam PBI demi memberikan kekuatan berlakunya, tetapi sebelum itu harus ditafsirkan dan diberikan masukan oleh KPS. Sepintas, sebagaimana 
ditegaskan dalam Pasal 3 PBI Nomor 10/32/PBI/2008 tentang Komite Perbankan Syariah, pembentukan KPS adalah sebatas untuk membantu Bank Indonesia dalam implementasi fatwa DSN-MUI. Namun sesungguhnya keberadaan KPS yang dibentuk oleh Bank Indonesia sama artinya dengan ketidakpercayaan terhadap DSN-MUI sebagai lembaga yang independen. Hal demikian karena wilayah tugas KPS berbenturan dengan kewenangan DSNMUI.

Tugas dan fungsi KPS menjadi sebatas untuk mengimplementasikan fatwa DSN-MUI ke dalam PBI, sebagaimana tertuang dalam Pasal 26 ayat (4) UU PbS merupakan hasil kompromi. Keinginan DPR selaku pengusul adalah melebur DSN-MUI ke dalam Komite Perbankan Syariah dan berada di bawah Bank Indonesia. Wacana ini menimbulkan kekhawatiran akan hilangnya identitas dan independensi DSN. Oleh karena itu wacana ini akhirnya dihilangkan. Namun ada rasionalitas kuat terkait eratnya kaitan antara fatwa syariah dan regulasi yang berada di bawah Bank Indonesia. Oleh karena itu diambil langkah kompromi untuk mengukuhkan (baca: mempertahankan) kedudukan DSN-MUI pada satu sisi dan menyetujui dielaborasinya Komite Perbankan Syariah di Bank Indonesia dengan kewenangan sebatas untuk menterjemahkan fatwa DSN-MUI ke dalam regulasi Bank Indonesia (Wibisnio, 2009: 111). Dengan demikian, seperti dijelaskan dalam paragraf terdahulu, sesungguhnya keberadaan KPS masih saja kontra produktif dan karenanya tidak diperlukan.

\section{Penutup}

Transformasi hukum Islam dalam hukum perbankan syariah, sebagaimana dikemukakan dalam uraian terdahulu, dapat disimpulkan sebagai berikut. Karakter khusus perbankan syariah yang membedakannya dengan perbankan konvensional adalah keharusan kepatuhan kepada hukum Islam di bidang ekonomi (fikih muamalah). Pengaturan tentang kepatuhan kepada hukum Islam telah dielaborasi sejak awal, dimulai pada periode UUP melalui PP BBH, pada periode UUP Baru melalui SK Direksi Bank Indonesia dan kemudian Peraturan Bank Indonesia, dan selanjutnya pada periode UU PbS, baik secara langsung dalam UU dimaksud maupun dalam PBI.

Hukum Islam yang menjadi dasar operasional bank syariah pada mulanya disebut dengan istilah prinsip bagi hasil dan kemudian digantikan dengan istilah prinsip syariah. Hukum 
Ijtihad, Jurnal Wacana Hukum Islam dan Kemanusiaan, Volume 14, No. 2, Desember 2014: 211-230

Islam dimaksud pada mulanya adalah fatwa DPS yang ada pada tiap-tiap bank syariah sebagai bagian dari pelaksanaan tugas pengawasan atas produk perbankan dalam menghimpun dana dari masyarakat dan menyalurkannya kepada masyarakat agar berjalan sesuai dengan prinsip syari'at. Pada perkembangannya hukum Islam dimaksud difatwakan oleh DSN-MUI sebagai bagian dari pelaksanaan tugas dan wewenang untuk memastikan kesesuaian produk, jasa dan kegiatan usaha bank syariah dengan prinsip syariah.

Fatwa DSN-MUI merupakan ijtihad kolektif para ulama dan pakar yang ahli di bidang persoalan ekonomi dan bisnis. Ciri spesifik fatwa DSN-MUI adalah motif pembaharuan hukum Islam dengan mengelaborasi kaidah tafrìq al-halàl minal ḥarām dan kaidah irädah alnaz̧ar.

Berbeda dengan fatwa DPS, fatwa DSN-MUI menduduki tempat yang istimewa dalam peraturan perundang-undangan, oleh karena kecuali ditunjuk dan mendapatkan legitimasi secara langsung dari UU PbS, juga sebagian telah diserap dalam UU tersebut dan berbagai PBI. Dengan demikian, fatwa DSN-MUI merupakan hukum yang mempunyai daya ikat secara mandiri.

Sebagai hukum yang ditunjuk dan mendapatkan mandat secara langsung dari UU PbS, fatwa DSN-MUI tidak memerlukan KPS untuk memberikan daya ikat bagi keberlakuannya. Penyerapan atau pengadopsian fatwa DSN-MUI ke dalam PBI, sesungguhnya merupakan langkah pengimplementasiannya dalam operasional bank syariah, bukan dasar keberlakuannya. Dalam konteks ini keberadaan KPS yang dimaksudkan untuk mentransformasikan fatwa DSN-MUI ke dalam PBI adalah kontra produktif. Munculnya KPS membuat alur transformasi hukum Islam dalam hukum perbankan syariah menjadi lebih rumit dan panjang serta mendegradasi validitas fatwa DSN-MUI.

\section{Daftar pustaka}

Ali, Zainuddin. Hukum Perbankan Syariah, cetakan kedua. Jakarta: Sinar Grafika, 2010. al-Zuhayli, Wahbah. Al-Wajīe fi Ușül al-Fiqh, cetakan kedua. Damaskus: Dār al-Fikr, 1995/ 1446.

Amin, Ma'ruf, "Pembaharuan Hukum Ekonomi Syariah dalam Pengembangan Produk Keuangan Kontemporer (Transformasi Fikih Muamalat dalam Pengembangan Ekonomi Syariah)," Pidato Ilmiah pada Penganugerahan Gelar Doktor Kehormatan 
Transformasi hukum Islam dalam hukum perbankan syariah di Indonesia (Ja'far Baehaqi)

dalam Bidang Hukum Ekonomi Syariah Disampaikan di Hadapan Sidang Senat Terbuka Universitas Islam Negeri Syarif Hidayatullah Jakarta, 5 Maret 2012.

Antonio, Muhammad Syafi'i. Bank Syariah dari Teori ke Praktik. Jakarta: Gema Insani Press, 2001.

Anwar, Syamsul. Studi Hukum Islam Kontemporer. Jakarta: RM Books, 2007.

Ash-Shiddieqy, T.M. Hasbi. Pengantar Hukum Islam. Jakarta: Bulan Bintang, 1994.

Azizy, A. Qodri. Membangun Fondasi Ekonomi Umat, Meneropong Prospek Berkembangnya Ekonomi Islam, cetakan I. Yogyakarta: Pustaka Pelajar, 2004.

Azizy, A. Qodri. Hukum Nasional, Eklektisisme Hukum Islam dan Hukum Umum, edisi revisi. Jakarta: Teraju, 2004.

Baehaqi, Ja'far. “Corak Pemikiran Hukum Islam Prof. K.H. Ali Yafie,” Skripsi tidak diterbitkan, Fakultas Syariah IAIN Sunan Kalijaga, 1999.

Basyir, Ahmad Azhar. Asas-Asas Hukum Mu'amalat (Hukum Perdata Islam). Yogyakarta: Perpustakaan Fakultas Hukum UII Yogyakarta, 1993.

Buang, Ahmad Hidayat dan M. Cholil Nafis, "Peranan MUI dan Metodologi Istinbat Fatwa dalam Undang-Undang Perbankan Syariah di Indonesia,” Jurnal Pengurusan 35(2012).

Departemen Agama Republik Indonesia. Pedoman Fatwa Produk Halal. t.tp.: Proyek Pembinaan Pangan Halal Ditjen Bimas Islam dan Penyelenggara Haji Departemen Agama Republik Indonesia, 2003.

Hosen, H.M. Nadratuzzaman dkk. Menjawab Keraguan Umat Islam terhadap Bank Syariah.Jakarta: Pusat Komunikasi Ekonomi Syariah Publishing, 2007.

Khallaf, Abdul Wahhab. Ilmu Ushul al-Fiqh, cetakan keduabelas. Kuwait: Dār al-Qalam, $1978 / 1398$.

Maksum, Muhammad, "Peran Fatwa DSN Dalam Menjawab Perkembangan Produk Keuangan Syariah,” dalam Asrorun Niam Sholeh (ed.), Fatwa Majlis Ulama Indonesia dalam Sorotan. Jakarta: Majelis Ulama Indonesia, 2011.

Mudzhar, H. M. Atho, “K.H. Ma'ruf Amin: Seorang Ulama yang Cemerlang dalam Ilmu Hukum Ekonomi Syariah dan Motor Penggerak Ekonomi Syariah Indonesia,” Pidato Promotor I, disampaikan pada Upacara Penganugerahan Gelar Doktor Kehormatan dalam Bidang Hukum Ekonomi Syariah kepada K.H. Ma'ruf Amin dalam Sidang Senat Terbuka Universitas Islam Negeri Syarif Hidayatullah Jakarta, 5 Maret 2012.

Mudzhar, H. M. Atho. Membaca Gelombang Ijtihad, antara Tradisi dan Liberasi. Yogyakarta: Titian Ilahi Press, 1998.

Muhaimin, "Dari Numerologi Hingga Fikih Sosial: Menyambut 70 Tahun Prof. K.H. Ali Yafie”, dalam Jamal D. Rahman (et. al.). Wacana Baru Fikih Sosial, 70 Tabun Prof. K.H. Ali Yafie, cetakan 1.Bandung: Mizan, 1997. 
ljtihad, Jurnal Wacana Hukum Islam dan Kemanusiaan, Volume 14, No. 2, Desember 2014: 211-230

Nafis, M. Cholil. Teori Hukum Ekonomi Syariah Kajian Komprehensif tentang Teori Hukum Islam, Penerapannya dalam Fatwa Dewan Syariah Nasional dan Penyerapannya ke dalam Peraturan Perundang-undangan, Jakarta: Penerbit Universitas Indonesia-UI Press, 2011.

Rofiq, Ahmad, "Eksistensi Hukum Islam di Indonesia; Perspektif Sejarah," makalah disampaikan dalam seminar "Konstitusionalisasi Hukum Islam dalam Sistem Hukum Nasional: Sebuah Kajian Historis dan Tinjauan Prospektif," yang diselenggarakan oleh Fakultas Syariah IAIN Walisongo, tanggal 14 Desember 2000.

Sjahdeini, Sutan Remy. Perbankan Islam dan Kedudukannya dalam Tata Hukum Perbankan Indonesia, cetakan ketiga. Jakarta: Pustaka Utama Grafiti, 2007.

Syam, H.M. Ichwan dkk. Fatwa Dewan Syariah Nasional Majlis Ulama Indonesia. Jakarta: DSNMUI, 2012.

Syam, H.M. Ichwan. Direktori Syariah Indonesia/Sharia Directory of Indonesia. Jakarta: Dewan Syariah Nasional MUI, 2011.

Syam, H.M. Ichwan. Tanya Jawab Seputar Dewan Syariah Nasional Majelis Ulama Indonesia. T.tp.: Dewan Syariah Nasional Majelis Ulama Indonesia, 2010 M/1431 H.

Syarifuddin, Amir. Pembaharuan Pemikiran dalam Hukum Islam. Padang: Angkasa Raya, 1993.

Umam, Khotibul, "Legislasi Fikih Ekonomi Perbankan: Sinkronisasi Peran Dewan Syariah Nasional dan Komite Perbankan Syariah," Mimbar Hukum, Volume 24, Nomor 2 (Juni 2012).

Wibisono, Yusuf, "Politik Ekonomi UU Perbankan Syariah Peluang dan Tantangan Regulasi Industri Perbankan Syariah,” Bisnis \& Birokrasi, Jurnal Ilmu Administrasi dan Organisasi, Volume 16, Nomor 2 (Mei-Agustus 2009).

Yafie, Ali. Menggagas Fikih Sosial, cetakan kedua. Bandung: Mizan, 1994. 